\title{
HISTORICAL DYNAMICS OF INTER-RELIGIOUS RELATIONS IN SOUTH KALIMANTAN ${ }^{1}$
}

\author{
Mujiburrahman \\ UIN Antasari, Banjarmasin - Indonesia | mujib71@hotmail.com
}

\begin{abstract}
This paper presents a historical overview of the dynamics of inter-religious relations in South Kalimantan. Early conversion to Islam in the $16^{\text {th }}$ century, and more intensive Islamization by the $18^{\text {th }}$ century, can be seen as the formative period of Islam in this region. The encounter and clash between the new religion and the existing beliefs and practices were unavoidable. By the late $19^{\text {th }}$ century, the clash seems to move to another target, namely the colonial power associated with Christianity. By this period, Islam was transformed from the court into a people movement against the colonial power. By the first half of the $20^{\text {th }}$ century, the problem of the $18^{\text {th }}$ century apparently reappeared but in another form, namely the clash between puritan and traditional Islam. The making of the Indonesian nation state by the second half of the $20^{\text {th }}$ century pushed the Banjarese Muslims to be involved in the ideological debates, and even in a rebellion against the state. During the Soeharto period, Muslim-Christian tensions at the national politics also influenced this region. Finally, in the Reformation Era, the Muslims in the province face serious challenges of intra- and inter-religious plurality.
\end{abstract}

Keywords: South Kalimantan, Banjarese, MuslimChristian, inter-religious relations.

\footnotetext{
1 This paper was originally presented at the "Workshop on the Growing Religious Intolerance in Indonesia," organized by the Postgraduate School of the State Islamic University, Sunan Kalijaga, Indonesia and Rajaratnam School of International Studies (RSIS), Singapore, held in Yogyakarta, 29 September - 1 October 2015. I would like to express my gratitude to Noorhaidi Hasan for his invitation to join the program and Uzair Fauzan who organized the workshop.
} 


\section{Introduction}

South Kalimantan is the oldest among the present five provinces of Kalimantan, the Indonesian parts of Borneo. In terms of ethnicity, most people of South Kalimantan are Banjarese, the tenth largest ethnic group in Indonesia. ${ }^{2}$ Like Malay identity, the Banjarese are generally identified as Muslim. The statistics of 2010 indicates that 99.55\% of Banjarese are Muslim. This is in line with the fact that Muslims comprise $97 \%$ of South Kalimantan population, and it is one of the 23 provinces in Indonesia categorized as exclusively Muslim. On the other hand, there are religious minorities in the region, including Protestants $(1.33 \%)$, Catholics $(0.44 \%)$, Buddhists $(0.32 \%)$ and Hindus $(0.44 \%) .^{3}$ Most of the Christians live in Banjarmasin, the capital of the province. The number of the Protestants is also significant in Banjarbaru municipality and Kotabaru district. The highest Hindu adherents are found in Central Hulu Sungai district, while most Buddhists are found in Banjarmasin and Balangan district. ${ }^{4}$

In general, like in many other places of the world, South Kalimantan is a plural society. The plurality of religion in this province is partly because of migration of people from the other parts of Indonesia. Many of them came to the region through the government transmigration program, and some of them by their own initiative. There are certainly some new converts, especially to Christianity and Buddhism. The Hindus are mostly adherents of local religion called 'Kaharingan' and 'Balian' considered by the state as a Hindu variant. There are also a few numbers of Balinese Hindus who migrated to this region. Moreover, the Muslim majority are not homogenous either. There are various Islamic groups in the region including the traditionalist Nahdlatul Ulama (NU), the reformist Muhammadiyah and Al-Washliyah, and the other groups such as Salafi-Wahabi, Lembaga Dakwah Islamiyah Indonesia (LDII), Ahmadiyah, Hizbut Tahrir Indonesia (HTI), Front Pembela Islam (FPI) and Shiah.

\footnotetext{
${ }^{2}$ Leo Suryadinata, Avi Nurvidya Arifin and Aris Ananta, Indonesia's Population: Ethnicity and Religion in a Changing Political Landscape (Singapore: ISEAS, 2003), pp. 31-68.

${ }_{3}^{3}$ Aris Ananta, Evi Nurvidya Arifin, M. Sairi Hasbullah, Nur Budi Handayani and Agus Pamono, Demography of Indonesia's Ethnicity (Singapore: ISEAS, 2015), pp. 263; 267; 270.

${ }^{4}$ BPS Kalimantan Selatan, Kalimantan Selatan dalam Angka 2015 (Banjarmasin: BPS Kalimantan Selatan, 2015), pp. 146-150.
} 
This paper discusses the dynamics of inter-religious relations in the region by highlighting some important cases occurred from the $18^{\text {th }}$ century up to the present. The 'inter-religious' here refers to the interaction between different religious groups of the same or different religions. In other words, the discussion will analyze the dynamics of relations among religious groups within Islam as well as between Islam and other religions. It is a historical overview described within the framework of continuities and changes along the period in question.

\section{Islamization vis-a-vis Pre-Islamic Beliefs and Practices}

According to Hikayat Banjar compiled by J.J. Ras, ${ }^{5}$ the first kingdom in South Kalimantan was Tanjungpura, located in Tanjung and established by Malay migrants of Sriwijaya Kingdom who followed Buddhism. In the $13^{\text {th }}$ century, the migrants from Java also established a kingdom called Negara Dipa in Amuntai, and they embraced Hinduism. Thus, it can be said that earlier kingdoms in the region were influenced by Buddhism and Hinduism. Conversion to Islam occurred later in the $16^{\text {th }}$ century. The first sultan who converted to Islam was Sultan Suriansyah (d.1550). We are told that the Banjarese Kingdom was taken over by the uncle of the crown prince. The crown prince's name is Samudera and his uncle called Temenggung. As a child, Samudera was saved by Patih Masih and lived with ordinary people in a village. When he became adult, Samudera wanted to take over the power from his uncle. He then asked the Islamic Sultanate of Demak, East Java, for military aid. The latter agreed on condition that the prince and his followers had to convert to Islam. With the military aid from Demak, Prince Samudera was confident to wage the war against his uncle. The war, however, finally did not take much bloodshed because the uncle, having looked at his nephew and talked to him, decided to surrender and returned the crown. Prince Samudera then converted to Islam and changed his name into Suriansyah. He was the first sultan of the Banjarese Sultanate.

The story of the conversion indicates clearly that it was political. ${ }^{6}$ The story may also indicate that the coming of Islam to this region was

${ }^{5}$ J.J. Ras, Hikajat Bandjar: A Study in Malay Historiography (The Hague: Martinus Nijhoff, 1968).

${ }^{6}$ For an analysis of different conversion myths in Indonesia, see Russel Jones, "Ten Conversion Myths from Indonesia" in Nehemia Levtzion (ed.), Conversion to Islam (New York: Holmes \& Maier, 1979), pp. 129-158. 
not totally in a peaceful way. This is in contrast to the common claim that Islam came to Indonesia peacefully through trade activities. It was also a top-down process, that is, conversion of a king followed by his subjects. It was probably still a formal conversion without deep understanding of beliefs and practices of Islam. However, the story also tells us, a man called Khatib Dayyan, was sent to the court, to teach Islam. Khatib Dayyan was probably not the only Islamic teacher came to this region. The fact that intensive Islamization already started by the 13 century in Sumatra, especially Aceh, it was very likely that other Islamic propagators also came to this region, earlier than Khatib Dayyan. ${ }^{7}$

The intensive Islamization of South Kalimantan was probably started by the $18^{\text {th }}$ century. The most important man behind the Islamization was Muhammad Arsyad al-Banjari (1710-1812). Sultan Tamjidillah I (d. 1767) sent him to Mecca and Medina to perform hajj and to learn all branches of Islamic traditional knowledge. After more than 30 years of study, he came back home and became the advisor to the Banjarese sultanate. The Sultan gave al-Banjari a piece of land called 'Dalam Pagar' (literally means 'inside the fence') where he lived and taught his students. Al-Banjari also wrote some Islamic books in Jawi (Malay language using Arabic characters), two of them are famous: Sabiil al-Mubtadin on Islamic Jurisprudence, and Tubfat alRäghibin on Islamic theology.

There have been scholarly debates on the authorship of the Tubfat al-Räghibin whether al-Banjari or Abd al-Shamad al-Palimbani (17371832). As discussed elsewhere, the arguments that the work is written by al-Banjari are quite strong. ${ }^{8}$ Moreover, Bradely argues that Dawud al-Pattani (d. 1847) wrote a translation of al-Banjari's Tubfat al-Räghibin which includes the work of al-Palimbani as well. ${ }^{9}$ For Mal'an Abdullah,

\footnotetext{
${ }^{7}$ For various arguments on this issue, see Yusliani Noor, Islamisasi Banjarmasin Abad ke15 sampai ke-19 (Yogyakarta: Ombak, 2016).

${ }^{8}$ Noorhaidi Hasan, "The Tuhfat al-Raghibin: the Work of Abdul Samad al-Palimbani or Muhammad Arsyad al-Banjari?" Bijdragen tot de Taal-, Land en Vulkenkunde Vol. 163 No.1 (2007), pp. 67-85; and Mujiburrahman, "Islamic Theological Texts and Contexts in Banjarese Society: an Overview of the Existing Studies" Southeast Asian Studies Vol.3 No.3 (December 2014): pp. 611-641.

${ }^{9}$ Francis R. Bradely, "The Social Dynamics of Islamic Revivalism in Southeast Asia, the Rise of Patani School 1785-1909," Ph.D Thesis, University of Wisconsin-Madison (2010), pp. 230-231.
} 
this may indicate that each of al-Banjari and al-Palimbani wrote a different treatise under the same title. ${ }^{10}$ In any case, the Tuhfat alRaghibin is a very interesting work especially because it covers tensions between Islamic orthodox theology and local beliefs and practices. In other words, this treatise shows us the interaction between Islam and the existing local culture in South Kalimantan, especially among the Banjarese.

In the treatise, al-Banjari describes the ritual practices called 'manyanggar' and 'mambuang pasilib' as opposed to the Islamic beliefs. AlBanjari, however, does not give us the definitions of the rituals, probably because he assumes that the Banjarese in his age already knew them. In the dictionary of Banjarese language, manyanggar means to put offerings. ${ }^{11}$ Asywadie Syukur ${ }^{12}$ in his study of the Tuhfat alRaghibin explains that manyanggar is a ritual in which people give certain offerings to evil spirits to appease them, and to avoid their bad influences, ${ }^{13}$ while mambuang pasilib is also an offering ritual performed for a family who is believed to have a hidden brother or sister. The ritual is carried out to prevent the hidden person from harming the family. ${ }^{14}$

10 Mal'an Abdullah, Syaikh Abdus-Samad al-Palimbani, Biografi dan Warisan Keilmuan (Yogyakarta: Pustaka Pesantren, 2015), pp. 96-97.

${ }^{11}$ Abdul Djebar Hapip, Kamus Banjar-Indonesia (Banjarbaru: Grafika Wangi Kalimantan, 2006), p. 164.

12 M. Asywadie Syukur, "Naskah Risalah Tuhfatur Raghibin" Interim report (Banjarmasin: IAIN Antasari, 1990).

13 A recent published book on Banjarese culture written by a number of scholars also mentions a ritual called manyanggar banua, which is by definition similar to manyanggar described by Syukur. If the two are identical, then the additional word banua (means region) is simply an explanation of the goal of the ritual, that is, to save people of a region (village) from disturbances of the evil spirits. See M. Suriansyah Ideham et al., Urang Banjar dan Kebudayaannya (Yogyakarta: Ombak, 2015), pp. 85-86.

${ }^{14}$ In contrast, for Abu Daudi mambuang pasilib is a ritual of throwing away someone's cloth to free him/her from bad luck. Daudi seems to translate the word pasilib into cloth. In Banjarese language, basilih means to change cloth, but pasilih can be something else. Daudi does not mention any empirical evidence to support his definition, while Syukur refers to a research report published in 1978. See Abu Daudi, Transliterasi Kitab Tubfaturraghibin (Martapura: Yapida, 2000), p. 70; and Asywadie Syukur, Pemikiran-Pemikiran Syekh Mubammad Arsyad al-Banjari dalam BIdang Taubid dan Tasawuf (Banjarmasin: Comdes, 2009), pp.10-16). The problem is, both manyaggar and mambuang pasilib are not practiced anymore. Alfani Daud who carried out a field 
Al-Banjari attacks the two rituals because for him they are against Islamic teachings. For al-Banjari, the rituals are the practice of tabdzir, spending goods excessively (in the offerings) without benefits, and the beliefs that the rituals could influence one's life is a kind of shirk, that is, associating God with other beings who have the power to control human life. Al-Banjari rejects the arguments of the actors of the rituals that the offerings were given to the unseen ancestors who spoke through a medium. For al-Banjari, in Islamic doctrines, the unseen creatures are either angles or satans. The fact that the rituals lead to tabdzir and shirk indicate that the unseen creature who receives the offerings should be satan.

In the Tubfat al-Răghibin, al-Banjari also criticizes a person pretending to be a Sufi but does not practice the Shari'a. For him, based on al-Ghazali's view, such a person deserves a death penalty. He said:

Imam Ghazali said, if a saint assumes that there is a position between him and God that abolishes the obligation to perform daily prayers, and allows him to drink alcohol as it is believed by pretending Sufis, then there is no doubt about the necessity to kill him because of his apostasy, and killing such a person is better than killing a hundred of genuine unbelievers. ${ }^{15}$

Al-Banjari's criticism of the local culture of rituals can be seen as evidence of tensions between Islamic orthodoxy and the existing preIslamic beliefs and practices. Before the acceptance of Islam, the Banjarese kingdom followed Buddhism and Hinduism, and the local religion had not been totally replaced by Islam or the other world religions. In general, al-Banjari's attack seems to be successful because both rituals are not practiced anymore. In addition, there are also some pre-Islamic rituals that have been Islamized, that is, by replacing their contents such as prayer and chanting with the Islamic ones. ${ }^{16}$ As we

research on Islam in Banjarese culture in 1980s did not mention them either. See Alfani Daud, Islam dan Masyarakat Banjar (Jakarta: PT Rajagrafindo 1997).

${ }^{15}$ Muhammad Arsyad al-Banjari, Tuhfat al-Räghibin (Banjarmasin: Toko Buku Murni, 1983), p. 32. This quotation is obviously taken from Muhammad bin Muhammad alGhazali, Faişal al-Tafriqah bain al-Isläm wa al-Zandaqah (Damascus: Mathba'ah al-Şabāh, 1993), p. 65.

16 See Alfani Daud, "Islamisasi Upacara Mandi-Mandi di Kalangan Masyarakat Banjar" Religika No.1 Vol.1 (2000), pp. 69-92. 
shall see, this kind of Islamized rituals have been accepted and practiced by the traditionalist Muslims but not by the reformists.

Moreover, al-Banjari's criticism of the mystics who claims to be beyond the shari'a law can be interpreted as a reaction to the existing pantheistic beliefs originated from Hinduism. Nevertheless, Asywadie Syukur presumes that al-Banjari's statement quoted above was used by the Sultan to punish Abdul Hamid Abulung who allegedly embraced pantheistic beliefs. ${ }^{17}$ However, as we can see, there is no direct reference to Abulung's case in the text of Tubfat al-Räghibin, and as far as I know, there is no historical evidence, apart from the oral tradition, that the case really happened. On the other hand, the legend of Abulung, as Steenbrink argues, can be a Banjarese version of al-Hallaj, similar to Siti Jenar as the Javanese one. ${ }^{18}$ In this regard, Feener argues that actually the legend of Siti Jenar, Abulung and the like is not directed against Hallajian doctrines, but against pantheistic views of Hinduism. ${ }^{19}$ Thus, we can say that both the text of Tubfat al-Raghbibin and the Abulung legend reflect the tensions between Islam and certain teachings of Hinduism that already existed in the region. ${ }^{20}$

\section{Islam versus Colonialism and Christianity}

By the $19^{\text {th }}$ century, Islam seems to be more established in the Banjarmasin Sultanate. Many of al-Banjari's students spread out to different parts of South Kalimantan and beyond, to teach people the beliefs and practices of Islam. The presence of Islam was then formally stated in the Constitution of Sultan Adam (1771-1857) issued in 1835, dictating, among other things, that people of Banjarmasin Sultanate should follow the orthodox Sunni theology (as formulated earlier by alBanjari), and anybody deviates from it should be reported to the Sultan and should repent. The image of the intimate relationship between Islam and the Sultanate was eventually embodied in the person of the

\footnotetext{
17 Syukur, "Naskah Tufatur."

18 Karel A. Steenbrink, Beberapa Aspek tentang Islam di Indonesia Abad ke-19 (Jakarta: Bulan Bintang, 1984), p. 96.

${ }^{19}$ R. Michael Feener, "A Reexamination of the Place of al-Hallaj in the Development of Southeast Asian Islam," Bijdragen tot de Tall-, Land end Vulkenkunde Vol. 154 No.4 (1998), p. 578.

${ }^{20}$ For more discussion on this issue, see Mujiburrahman, "Islamic Theological Texts", pp. 616-618.
} 
Sultan himself. Sultan Adam, for instance, especially in his old age, was considered a saint by his people. ${ }^{21}$

Like some other local kingdoms in the archipelago, the Banjarmasin Sultanate in the 19th century was under the Dutch colonial control. Earlier contacts between the Banjarmasin Sultanate and the Dutch for trade activities started by the late $16^{\text {th }}$ century, and became more intense by the $17^{\text {th }}$ century. The relationships between the parties fluctuated between conflicts and cooperation. By the first half of the $19^{\text {th }}$ century, however, the Dutch successfully forced the Sultan to sign contracts allowing the former to control certain areas of the Sultanate, and that any new Sultan cannot be crown without the Dutch endorsement. ${ }^{22}$

In line with the history of colonialism, the Christian missionaries from Europe came to South and Central Kalimantan by the late $17^{\text {th }}$ century. The early mission of the $17^{\text {th }}$ and $18^{\text {th }}$ centuries was not successful, and the missionaries were generally killed by the local people. The mission was to be more successful when Rheinische Missionsgessellschaft (RMG) from Germany started its works in the region by the $19^{\text {th }}$ century. The missionaries developed certain strategies to attract people, especially the Dayaks, such as offering education and health services, establishing 'kinship' ties with local leaders through a certain Dayak ritual, and freeing those people who could not pay their debt. 23

In general, the Dutch did not have effective control over the Dayaks who lived in remote areas. Therefore, for mutual benefits, the cooperation between the Dutch colonial administration and the missionaries was necessary, even though each of them had different

21 Helius Sjamsuddin, Pegustian dan Temenggung:Akar Sosial, Politik, Etnis dan Dinasti Perlawanan di Kalimantan Selatan dan Kalimantan Tengah 1859-1906 (Yogyakarta: Ombak, 2014), p. 113; Virginia Matheson "Conflict Without Resolution: the Banjarmasin War 1859-1905," Paper presented at the fourth Conference of Asian Studies Association of Australia, at Monash University, May 10-14 (1982), p. 3.

22 Sjamsuddin, Pegustian dan Temenggung, pp. 66-80. For an interesting account of the local contacts with foreigners in the Banjarese Sultanate from a Japanese source, see Nomura Toru, "Magotaro: An Eighteenth Century Japanese Sailor's Record of Insular Southeast Asia," Sari 27 (2009), pp. 45-66.

23 Sjamsuddin, Pegustian dan Temenggung, pp. 80-90; A. Eddy Kristiyanto, Sejarah Keuskupan Banjarmasin (Banjarbaru: Grafika Wangi, 2013), pp.49-54; Douglas Miles, Cutlass and the Crescent Moon: A Case Study of Social and Political Change in Outer Indonesia (Sydney: Center for Asian Studies, Sydney University, 1976), pp. 103-106. 
goals. The fact that both missionaries and colonial administrators were white people who followed Christian beliefs made this cooperation more natural. This was probably the reason why the Banjarese put both the Dutch colonialists and the missionaries in the same boat as the Christian enemy. In other words, the religious identity became strongly political in which the Banjarese identified themselves as Muslims versus the Dutch and European Christians.

The Banjarese War (1859-1906) was evidence of the significance of religious identities involved, especially for the local Muslim 'rebels'. ${ }^{24}$ The war started with the political crisis in the court on the question of succession. In 1825, Sultan Adam appointed his oldest son, Abdul Rakhman, as a crown prince holding a position as a young sultan. However, Abdul Rakhman passed away in 1852 while the very old Sultan Adam was still alive. There were three candidates competing to be the successor of Sultan Adam: Tamjidillah, Hidayatullah and Prabu Anom. The Dutch preferred Tamjidillah to the other candidates. The Sultan favored Hidayatullah, while his wife, Queen Kemala Sari wanted his youngest son, Prabu Anom. The Dutch finally forced its will, appointing Tamjidillah as the next crown prince. The Banjarese people, however, were disappointed with the Tamjidillah appointment. They did not like him because he was not a pious Muslim. He liked alcoholic drinks and followed European lifestyle. He also did not feel disturbed by the fact that his two sisters lived together with European men without marriage. In contrast, Hidayatullah was a pious man and close to the people. Moreover, his mother was among the aristocrat family, while Tamjidillah's mother was not.

The war finally broke in 1859, and the Dutch decided to abolish the Banjarese Sultanate by the next year (1860). The war was initially led by Antasari (1809-1862), another neglected prince who had sympathy with Hidayatullah. In the beginning, the 'rebels' attacked a coal mining in Pengaron controlled by a Dutch company called Oranje Nassau. The Christian missionaries and their families were also attacked. Many of them were killed and some of them successfully escaped. Many of the Antasari supporters were the hajjis, people who

\footnotetext{
${ }^{24}$ The following summary of the war is taken from Helius Sjamsuddin's Pegustian dan Temenggung, so far the most comprehensive study of the subject. The earliest study of the war in English is probably M. Idwar Saleh, "Agrarian Radicalism and Movements of Native Insurrection in South Kalimantan," Archipel Vol. 9 (1975), pp. 135-153. Another study is by Matheson, "Conflict Without Resolution".
} 
already performed the Muslim ritual of hajj in Mecca. According to the Dutch reports, in the $19^{\text {th }}$ century, a high number of Banjarese (even the highest in the Dutch Indies) went for pilgrimage. These people were relatively prosperous and lived a pious life. Most of the hajjis, especially those who lived in villages and far from the capital Banjarmasin, were haters of the Dutch perceived as Christian colonialists. Moreover, Antasari was supported by the so-called Beratib Beamal movement. This movement was probably a Sufi Order. ${ }^{25}$ By performing a certain ritual and prayer, the followers of Beratib Beamal were said to be invulnerable and very brave to fight. They considered the war against the Dutch as jihad, a holy war against the infidels for which someone could die as a martyr deserving a happy life in the paradise.

\section{The Reformist versus the Traditionalist}

If the $18^{\text {th }}$ century of Banjarese people contained the tensions between Islam and pre-Islamic beliefs and practices, and the $19^{\text {th }}$ century between Islam and Christianity associated with colonialism, the first half of the $20^{\text {th }}$ century came with another tension, namely between the traditionalist Islam versus the reformist one. This is, however, in a way can be seen as a continuity of the tension came up in the $18^{\text {th }}$ century.

The emergence of the Islamic reform movement in the Middle East and India eventually influenced the other Muslims in the world, including the people of the archipelago. As has been discussed, many

\footnotetext{
${ }^{25}$ Helius Sjamsuddin speculates that it was a Naqshabandiyah Order based on a Dutch report on South Kalimantan in January 1889 which mentions this order's name but without direct reference to Beratib Beamal. Sjamsuddin, Pegustian dan Temenggung, pp. 256-257. In contrast, Martin van Bruinessen assumes that Beratib Beamal was a Sammaniyah Order due to the fact that the name of Antasari's son who continued the war after the death of his father was Muhammad Seman, the name of the founder of the Sammaniyah. Moreover, the reading ritual of the hagiography of Syekh Samman is still common among the Banjarese. Martin van Bruinessen, Kitab Kuning, Pesantren dan Tarekat (Yogyakarta: Gading, 2012), pp. 381-382. It is noteworthy that Muhammad Arsyad al-Banjari was a student of Muhammad Samman when the former studied in Medina. Muhammad Zaini bin Abdul Ghani (1942-2005), the latest most influential ulama of al-Banjari's descents, started introducing the Sammaniyah Order to his followers in 1994. A. Athaillah, "Perkembangan Tarekat Sammaniyah di Kalimantan Selatan," Khazanab Vol.3 No.2 (2004), p. 227. On the other hand, the Naqshabandiyah Order has also developed in South Kalimantan, and before the 1994, more noticeable than the Sammaniyah.
} 
Banjarese went to Mecca and Medina since the $18^{\text {th }}$ century, not only to perform hajj but also to study Islam. By the late $19^{\text {th }}$ century and early $20^{\text {th }}$ century, many of the Banjarese also went to Cairo, to study Islam in the famous al-Azhar University. Like the other Muslims of the archipelago, the Banjarese went to Cairo partly to avoid the rise of the influence of the Wahabi reformist movement in Saudi Arabia. However, in al-Azhar, they also met Muhammad Abduh (1845-1905) and his student, Rashid Rida (1865-1935), the important reformistmodernist leaders in that period.

Moreover, in 1901, the Dutch colonial government introduced the so-called 'Ethical Politics', a policy to open the opportunities for the indigenous people to have modern education. This modern education eventually produced a new generation of leaders of the independent movement. The new generation established organizations based on Islamic and/or nationalist ethos. Among the Islamic organizations were Sarekat Islam, founded in 1912 in Surabaya, Muhammadiyah, founded in 1912 in Yogyakarta, and Nahdlatul Ulama (NU), founded in 1926 in Surabaya. In South Kalimantan, the first branch of Sarekat Islam was established in Banjarmasin in 1914, while the first branches of Muhammadiyah and NU were established in Alabio in 1925, and Martapura, in 1927, respectively. Later on, in 1931, a local traditionalist Muslim organization called 'Musyawaratut Thalibin' was also established. All of these organizations developed educational institutions, teaching religious as well as modern knowledge. ${ }^{26}$

As described in Deliar Noer's study, ${ }^{27}$ by the first decades of the $20^{\text {th }}$ century, tensions between the so-called 'the young' reformist (kaum muda) and 'the old' (kaum tua) traditionalists occurred in West Sumatra, South Sulawesi and Java. The reformists represented by Muhammadiyah and Persatuan Islam, while the traditionalists represented by Nahdlatul Ulama and Tarbiyah Islamiyah. In general, the reformists rejected all local religious practices originated from preIslamic local culture. The traditionalists, on the other hand, accepted those practices because in their view, they were already Islamized. For the reformists, Muslims became backward because they still believed in

\footnotetext{
26 See Syaharuddin, "Organisasi Islam di Borneo Selatan 1912-1942: Awal Kesadaran Berbangsa Urang Banjar," Master Thesis. Yogyakarta: Faculty of Humanities, Gadjah Mada University (2008).

${ }^{27}$ Deliar Noer, Gerakan Modern Islam di Indonesia 1900-1942 (Jakarta: LP3ES, 1980).
} 
superstitions and supra-natural power other than God alone. For the traditionalists, the reformists were too simplistic in their understanding of Islam, ignoring the importance of relations between Islam and local culture. Both camps certainly used religious texts to support their respective positions.

In South Kalimantan, the tensions also broke up. In 1926, in Amuntai, the colonial government even facilitated a forum for debate between the two camps. Idham Chalid (1922-2010) who was to become the national NU leader also said that in early 1930s, when he was still a child, he witnessed the tensions between followers of traditionalist and reformist ulama in Amuntai. The controversy was on how to perform the intention (niyyah) when someone starts the prayer ritual. Idham does not explain in detail this case. This type of controversy, however, is quite well known. For the traditionalist, in order to put the intention precisely in one's heart, he or she could recite it (al-talaffu:), while for the reformist the recitation should not be done because it is never taught by the prophet. Idham Chalid said that this controversy led to animosity, quarrel and even physical violence. In 1937, Idham Chalid studied in Nagara of South Hulu Sungai District where he also found another case of religious conflict, namely on the validity of Friday prayer in a newly built mosque. The controversy was on the precise distance between the old mosque and the new one. Some said, it already fulfilled the minimum distance according to the standard of the Shafi'ie school, while some others said, it did not. This controversy seems to be among the traditionalists themselves, that is, between the conservative and the progressive group. ${ }^{28}$

Another case was the competition between the two camps to control over a mosque in Alabio in 1931 which eventually invited the colonial security guard to stop them. Probably because of this early tensions, up to now one can see the identification of mosques with the traditionalist Nahdlatul Ulama or the reformist Muhammadiyah in their respective nameplates. Usually, in South Kalimantan and probably in many other places in Indonesia, only the mosques of Muhammadiyah identified themselves in their nameplate, not those of the Nahdlatul Ulama. In 1946, a leader of the reformist camp in Alabio

28 Arief Mudatsir Mandan, Napak Tilas Pengabdian Idham Chalid Jakarta: Pustaka Indonesia Satu, 2008), p.65 and pp. 68-69. 
was arrested and then killed by the colonial security. Rumor said that he was reported by a traditionalist man to the Dutch authorities for his involvement in a rebellious movement against the Dutch. In 1949, a traditionalist ulama was kidnapped and killed by unknown people. Rumor said that it was a revenge of the 1946 case. ${ }^{29}$ Apart from the credibility or falsity of the rumors, they clearly indicate that there were strong tensions, suspicions and even hatred between the two camps.

\section{Soekarno Era: the Politico-Ideological Tensions}

After the defeat of the Japanese from the Allied in the Second World War, Soekarno and Muhammad Hatta declared Indonesian Independence in Jakarta, 17 August 1945. However, this important event was not widely known in South Kalimantan, partly due to the scarcity of the means of communication. ${ }^{30}$ The radios were previously seized by the Japanese colonialists. When the army of NICA (Netherlands Indies Civil Administration) came to South Kalimantan, the local aristocrats tended to submit themselves to the former boss rather than joining the republicans. Feeling concerned with this problem, some Banjarese who lived in Java sent a group of army from Surabaya to fight against the Dutch, but they were finally defeated. There were also a few sporadic attacks in Banjarmasin, but the Dutch could control the situation soon.

A more organized opposition to the Dutch started by the late 1946, when a division of marine of the Republican Army led by Hassan Basry waged a guerrilla war. Basry was a Banjarese, educated in the modern Islamic boarding school, Gontor, East Java. The guerilla war was quite disturbing for the Dutch, and Basry was difficult to find. He hid in the forest of the Meratus hills where the Dayaks lived. When the political negotiation of the nationalist leaders and the Dutch came to a compromise that a federal state to be established, on 17 May 1949, Hassan Basry declared South Kalimantan to be part of the United Indonesia, rejecting the federal idea.

\footnotetext{
${ }^{29}$ Achmad Fedyani Saifuddin, Konflik dan Integrasi: Perbedaan Faham dalam Agama Islam (Jakarta: Rajawali Pers, 1986), pp. 55-57.

30 The following account is based on Hassan Basry's memoir, Kisah Gerila Kalimantan (Banjarmasin: Jajasan Lektur Lambung Mangkurat 1961). This is the first volume. In 2003, the first and the second volumes were published together. See Hassan Basry, Kisab Gerilya Kalimantan Tabun 1945-1949 (Banjarmasin: Yayasan Bhakti Banua, 2003).
} 
However, after the power hand over from the Dutch in the same year to the republican leaders took place, Hassan Basry seems to be marginalized. Instead of being appointed in a formal position, in 19501953 he was sent to Cairo to study at al-Azhar University and American University. There is no doubt that he and his followers were disappointed. Having disappointed, one of his colleagues, Ibnu Hadjar, decided to fight against the new republic. Ibnu Hadjar called his group as Union of the Oppressed People (Kesatuan Rakjat jang Tertindas). This group eventually joined the Darul Islam movement, established by Kartosuwiryo in West Java. Ibnu Hadjar's rebellion survived for about nine years (1950-1959). He was later reportedly executed by the government. ${ }^{31}$

When Hassan Basry and his followers waged the guerrilla war, like Antasari movement of the $19^{\text {th }}$ century, they believed that it was a holy war against the infidel Dutch. However, it did not necessarily mean that they wanted an Islamic ideology for the state. Likewise, Ibnu Hadjar's decision to join the Darul Islam movement was much more motivated by disappointment with the government policy towards former guerilla armies rather than by the Islamic ideology. Nevertheless, Islam as a political identity was quite strong among the Banjarese, and therefore, Islamic ideology certainly attracted them. Two years before the first Indonesian elections, when Soekarno visited Amuntai in 27 January 1953, some people brought a banner written on it: Islamic or national state? In his speech, Soekarno openly spoke that for the unity of the whole nation, he favored the nationalist ideology. ${ }^{32}$ In fact, the result of the elections of 1955 in South Kalimantan was in favor of the Islamic parties. NU and Masyumi obtained 48.6\% and $31.9 \%$ votes respectively. 33 At the national level, during the

${ }^{31}$ See C. van Dijk, Rebellions under the Banner of Islam: the Darul Islam in Indonesia (Leiden: KITLV, 1981); Muhammad Iqbal "Kesatuan Rakjat yang Tertindas (KRjT): Pemberontakan Ibnu Hadjar di Kalimantan Selatan 1950-1963," Master Thesis. Jakarta: Department of History, University of Indonesia (2014).

32 For a specific study of the case, see Muhammad Iqbal, "Menyulut Api di Padang Ilalang: Pidato Politik Soekarno di Amuntai, 27 Januari 1953," Undergraduate Thesis. Yogyakarta: Department of History, State University of Yogyakarta, 2009.

${ }^{33}$ Herbert Feith, Pemilihan Umum 1955 di Indonesia. Trans. Nugroho Katjasungkana, Masri Maris and Prakitri Simbolon (Jakarta: Kepustakaan Populer Gramedia, 1999), pp. 114-115. 
Constituent Assembly following the elections, the two parties spoke for Islam as an ideology of the state.

The Dayak people, particularly those who embraced Christianity or local religions of Balian and Kaharingan, were understandably worried about the Islamic political ideology. Many Dayaks also could not accept that the Banjarese, being more educated, dominated important government positions in the region. During the late Dutch colonial era, the Dayaks of Central Kalimantan used to ask for an independent government from the Banjarese. This demand was not entirely successful due to the coming of the Japanese interlude. During the revolutionary war, the Dayak elites tried to be a part of the 'Dutch sponsored' Federal States, but this also failed. The moment then came when Ibnu Hadjar rebellion emerged in the 1950s. By this time, the Dayaks organized themselves as the defenders of the state nationalist ideology, Pancasila. They then demanded the central government to give them a province separated from the Banjarese. This demand was finally accommodated by the Soekarno government in May 1957, and a new Central Kalimantan Province was established. The political struggle after the formal partition, however, was not free from violence. ${ }^{34}$

\section{Soeharto Era: From Fear of Christianization to Social Frustration}

The rise of Soeharto to power, following the abortive coup of 1965, was strongly supported by the Islamic groups, especially the reformists. Nevertheless, Soeharto eventually marginalized the Islamic groups in the political stage. He refused the rehabilitation of the reformist Muslim party, the Masyumi, and did not allow former leaders of the Masyumi to lead the newly established party, Parmusi. Soeharto and the military also allied with the Christians and the secular oriented Muslims in opposing the Islamic ideological ambition of the Islamic groups.

This Muslim political frustration was exacerbated by the effects of the mass killing of hundreds of thousands of the former communists and suspects. The communists were considered atheists, and therefore, against the state ideology, Pancasila, which recognizes the belief in God. In order to avoid the murder, many of the Javanese nominal Muslims (abangan) converted to one of the world religions, and a high

${ }^{34}$ Miles, Cutlass and the Crescent Moon. 
number of them converted to Christianity. The mass conversion to Christianity and the wave of foreign aid for missionary activities were reported in Western media. Having realized this issue, the leaders of the Islamic groups started worrying about what was to be called 'Christianization', that is, Christian unfair efforts to convert Muslims. In 1967, the Muslims demanded the government to control foreign aid for religious institutions and to limit religious missions only to the people outside the 'recognized' (world) religions, but the Christians disagreed because for them the demands are against religious freedom. ${ }^{35}$

The Muslim-Christian tensions at the national politics also echoed in Banjarmasin. In 19-21 April 1969, the Office of the Ministry of Religious Affairs, South Kalimantan Province, held a meeting with the leaders of religious groups. ${ }^{36}$ In this meeting, E. Saloh, a Protestant Minister of the Kalimantan Evangelical Church (GKE), said that he disagreed with the working paper presented in the meeting that religious mission should be limited only for those outside the followers of the recognized religions. For him, the target of religious mission should be all human beings, as it is dictated in the Bible. ${ }^{37}$ Saloh was the chairman of the GKE Synod (1962-1968), and the GKE is the biggest church in South and Central Kalimantan. Therefore, Saloh's voice was important and understandably, incited reactions. A prominent Muslim leader, Rafi'i Hamdie, interrupted and asked the chairman of the meeting to warn Saloh not to talk about issues that would lead to conflict and animosity. The chairman finally decided to stop the meeting. After the meeting, Islamic reformist student organizations such as Islamic Indonesian Students (PII), Association of Muslim Students (HMI) and Muhammadiyah Student Organization (IMM) released a statement of protest against Saloh's remarks in the meeting. The national media of Muslim reformists such as Abadi

35 See Mujiburrahman, Feeling Threatened: Muslim-Christian Relations in Indonesia's New Order (Amsterdam: Amsterdam University Press, 2006), Chapter 1.

36 The following account is based on the document compiled by Pelajar Islam Indonesia (PII), Kristenisasi di Kalimantan Selatan (Peristiwa 'Salob' dengan Rangkaianja) Bandjarmasin: PW PII Kalsel, 1969. See also Mujiburrahman, Mengindonesiakan Islam, Representasi dan Ideologi (Yogyakarta: Pustaka Pelajar, 2008), pp. 378-390.

${ }^{37}$ In Indonesia, 'the recognized religions' mean those religions administered, protected and supported by the state. The religions are Islam, Protestantism, Catholicism, Buddhism, Hinduism and Confucianism. 
newspaper and Kiblat magazine also covered the story. On 13 May 1969, both Catholic and Protestant leaders released a statement explaining Saloh's position, namely that religious missions should be directed to all human beings through the ways that respect human rights and Pancasila values. The controversy did not immediately stop until the governor, the police and the army interfered. ${ }^{38}$

Another case of the Muslim fear of Christianization was their opposition to the Assembly of the GKE Synod in 1988. It is noteworthy that at the national level, in 1975 the Islamic groups rejected the World Council of Church (WCC) Assembly to be held in Jakarta. The Assembly was finally cancelled and moved to Nairobi. ${ }^{39}$ The case of GKE Synod Assembly was rather different. According to Darius Dubut, ${ }^{40}$ a GKE minister who attended the meeting, it was held in the House for Teacher Training (Balai Penataran Guru, BPG), Banjarbaru. At that time, Banjarbaru was still a part of the Banjar district and Martapura was the capital. Martapura is well-known as a Muslim dominated district and proudly calls itself the Veranda of Mecca. There was a rumor that the Assembly was to discuss a plan to build the biggest church in Kalimantan, to be located at the crossroad of Martapura and Banjarbaru. Therefore, the ulama and people from Martapura objected to the Synod Assembly.

The regent of Banjar distict then invited the GKE leaders, the ulama and the government authorities. In that meeting, the GKE explained that the Synod Assembly was a cross-provincial event, and therefore, the permission was given by the Police National Headquarter. Because the Assembly already got the permission, the regent said that the local government should allow it to proceed. The protesters asked the regent to allow them to read their letter, but the regent disagreed. The letter was then given to the GKE leaders. Its content was simply a rejection of the Synod Assembly. Nevertheless, the GKE leaders decided to go on.

\footnotetext{
38 According to Ilham Masykuri, the son of Rafi'i Hamdie, the controversy stopped after a meeting in a cafe where Rafi'i Hamdie finally realized that he had a family tie with Saloh.

${ }^{39}$ Mujiburrahman, Feeling Threatened, pp. 62-69.

40 The following account is based on my interview with Darius Dubut, 27 September 2015. According to Dubut, all documents of the Assembly were lost because of fire.
} 
The Assembly was opened on Tuesday evening. On Wednesday, a Muslim man came to the Assembly, asking to be allowed to participate, but the Synod rejected him. By Wednesday evening, a lot of polices and armies came to the area around the place of the Assembly, to guard it from people demonstrating against it. They were finally pushed by the securities to go back home. By Thursday, there was a rumor that after the Muslim Friday prayer, there would be a huge demonstration. The commander of the army base, in Banjarbaru, who happened to be a Batak Christian, suggested that the Assembly to be moved to the army base. The leaders of the GKE, however, decided to stay in the place, but they attempted at finishing the Assembly earlier than the schedule. So, the Assembly was finished on Friday morning, and they immediately came back home, guarded by the security forces.

The last and most important case during the New Order period is the riot in Banjarmasin, on 23 May 1997. It was on Friday. I was riding a motorcycle to the State Institute of Islamic Studies (IAIN), Antasari through the Ahmad Yani Street. I was surprised to see many people, with green cloth written on it the symbol of Islamic party, PPP. They came and went without obeying the traffic rules. Some of them were holding a sword or a sickle. When I arrived at the IAIN, students told me that a riot happened at the center of the city. We then saw a black smoke of fire, climbing to the sky. I came back home. In the evening, I heard from the loud speaker of the mosque an announcement from the security that everybody was not allowed to go outside.

What happened?41 According to the studies of the riot, the day was the last turn for the government party, Golkar, to campaign for the elections. For this reason, some ministers and high state officials came to Banjarmasin. On that Friday, Muslim males prayed in the Noor Mosque. Some of them prayed in the street close to the mosque. In the mid of the praying, a few motorcycles riders crossed the street, who were supposed to support the Golkar campaign, annoying the congregation. The people in the mosque were angry. They started

\footnotetext{
41 The following account is based on Hairus Salim, Amuk Banjarmasin (Jakarta: YLBHI, 1997); Mochtar Mas'oed, Mochammad Maksum and Muhammad Soehadha (eds.), Kekerasan Kolektif, Kondisi dan Pemicu (Yogyakarta: P3PK Universitas Gadjah Mada, 2000). See also Husnul Khotimah, "Collective Memory Jumat Kelabu di Kota Seribu Sungai (Studi Kasus Kerusuhan Sosial 23 Mei 1997 di Provinsi Kalimantan Selatan dalam Perspektif Bina Damai)," Master Thesis. Yogyakarta: Postgraduate Program, State Islamic University, Sunan Kalijaga (2016).
} 
destroying any Golkar symbol and burned two Golkar offices. They also burned Mitra Plaza shopping center, and took goods inside. They then burned a lot of shops, especially those belong to Chinese. Later, places of religious worship also became their target. Five churches and three viharas were burned. In this riot, 121 persons were reportedly dead, and 123 were injured. Several reportedly disappeared.

The riot was not religious, but religious symbols certainly played a part. During the New Order, South Kalimantan, especially Banjarmasin, was the strong power base of the Islamic party, PPP. This is not surprising due to the fact that the president of the party was a Banjarese, Idham Chalid. The support for the PPP was also in line with the high vote for the Islamic parties in the 1955 elections. Nevertheless, during the New Order, as the government party, Golkar used any means to win the elections. After more than 30 years, the economic gaps between the few rich and the poor mass became wider and wider. People were trapped into political and economic frustration. Moreover, the national political elites were not totally in support of Soeharto anymore. He was too long in power, and people wanted a new leader. It was in this context that some observers said that the riot could be orchestrated by outsiders. However, even if there were provocateurs, the riot would not happen if the condition of the people was not ready for it.

\section{The Reformation Era: the Challenges of Plurality}

Since the fall of Soeharto in 1998, Indonesia has been developing into a democratic polity. Indeed, it could be argued that Indonesia is the most democratic Muslim country in the world today. At the same time, the country has witnessed the emergence of various Islamic groups, especially those with radical tendencies. The free public sphere of democracy has opened the door for the encounter of religious differences.

South Kalimantan is not an exception. As has been discussed above, by the $18^{\text {th }}$ century, Arsyad al-Banjari opposed the pre-Islamic beliefs and rituals, by the $19^{\text {th }}$ century, Antasari fought against colonialism associated with Christianity, and by the $20^{\text {th }}$ century, the reformist Muslims attacked some of the traditionalist Muslim beliefs and practices. All of these problems are still found now, but the plurality of religious groups and teachings have significantly increased. Within the Islamic community, there exist not only the traditionalist 
NU and the reformist Muhammadiyah, but also Ahmadiyah, Shiah, Salafy, Islam Jamaah, Hizbut Tahrir Indonesia (HTI) and Front Pembela Islam (FPI). Moreover, the adherents of religions other than Islam are also more present in the public sphere than before. With the rise of democracy, they seem to have more courage to show their objection to any discrimination and to speak for their rights as equal citizens. Inter-religious meetings have also been more often than before.

The problem of internal plurality of Islamic community in South Kalimantan is quite crucial to solve. Tensions sometimes occur even among the well-educated people in a public seminar and discussion. Fortunately, as far as I know, violence never happens among them. One of the most outspoken Islamic group in this region is HTI whose followers mostly university students and mostly from 'secular' universities such as Lambung Mangkurat University and the Academy of Education and Teacher Training (STIKIP), and some of them from the State Islamic University (UIN). The discourses of the HTI ranging from global political issues, especially criticisms of the United States and Israel with all conspiracy theories, to the dream of establishing an international Islamic government under an Islamic leader, a khalifa. One of the important political discourses of the HTI is that democracy is kufr (infidel). The HTI attracts young people since their high school years when they join Rohis (Kerohanian Islam, the Islamic Spritual Club). The activists of Rohis then join the Institute of Islamic Propagation in Campus called LDK (Lembaga Dakwah Kampus). ${ }^{42}$ Some of them, however, start joining the group when they become university students. In general, the young people feel that the world is morally chaotic and politically unjust. They then find the Islamic ideology as the only alternative answer.

I have several experiences to talk in a public discussion where the HTI activists participated. They are usually very enthusiast and sometimes their friends shout 'Alläbu Akbar' (God is the Greatest). Elsewhere, I describe one of my personal experiences about this as quoted below.

On one occasion, I was invited to be a moderator of a discussion on the issue of Islamic brotherhood. It was in Banjarbaru, a district 20 kilometers from the capital, Banjarmasin, South

${ }^{42}$ It does not mean that all LDKs are HTI's followers. 
Kalimantan. The speakers were Muhammad al-Khattath, the national leader of Hizbut Tahrir Indonesia (HTI), Anwar Abbas, the national leader of Muhammadiyah, and Said Agiel Siradj, the leader of Nahdlatul Ulama (NU). These three speakers were considered representatives of different Islamic organizations in Indonesia: the Muhammadiyah is reformist, the $\mathrm{NU}$ is traditionalist and the HTI is trans-nationalist.

From the very beginning, the organizers realized that tensions could easily emerge. Therefore, they asked me as a moderator to manage the discussion in such a way that everybody could feel comfortable. Having made a few introductory remarks, I gave the first opportunity to al-Khattath. As the leader of the HTI, he explained that his organization's primary work is in the field of politics. The HTI's ambition is to achieve global unity of political Islam under the so-called 'khilafah system'. For him, every Muslim should struggle for global political supremacy, and the enemy is apparently nothing other than the United States and Israel with their global capitalist economic hegemony. When the khilafah is established, Islamic law (shari ${ }^{\bar{a}}$ ) ) will be implemented. The second chance was given to Said Agiel. He said that NU accepted the Indonesian state, and that for NU, Pancasila is final. Pancasila can be accepted because it is in line with Islamic values. The state could accommodate Islamic rules if they are approved by the Parliament. However, to follow the shari'a, Muslims do not always need the state. He then attacked what he called 'formal Islam'. "For you who have a beard, I will say that it is not an important mark of being a Muslim. Remember, Abu Jahal, the enemy of Prophet Muhammad, also had a beard. And you, Muslim women who wear the head covering. You must know that head covering is only one tiny rule in the Qur'an. Most of the Qur'anic teachings talk about justice, equality and protection of the weak," Said Agiel said.

The HTI activists and supporters, who heard Said Agiel Siradj's remarks were hot and angry. Before giving a chance to Anwar Abbas to speak, I whispered to him. "Please try to calm down the situation!" He said, "Yes, do not worry!" Then I began. "Ladies and gentlemen, our last speaker is Anwar Abbas. He is an economist. We must listen to him because, it is possible that the different views between al-Khattat and Said Agiel are not that important compared to the economic problems." Anwar Abbas then took his chance. He started with a kind of play. "Please answer 'yes' if you agree with my statement, and 'no' if you don't." 
He then asked, "Do you agree that all Muslims in Indonesia should be rich?" "Yes...." said all participants together. "So, let's forget our differences, and start thinking about our common interest: the economic interest." Everybody then seems to feel relieved and laughed. The discussion afterwards was still hot, but did not lead to violence. ${ }^{43}$

For the HTI and the like, however, a country will not become prosperous until it implements shari'a law. This is actually one of the crucial issues during the first decade of the Reformation Era in several parts of Indonesia, including Banjarmasin. ${ }^{44}$ One of the issues incited public controversy was the so-called 'Perda Ramadan', a Regional Regulation for Ramadan, the Muslim fasting month. ${ }^{45}$ The major of Banjarmasin issued the Regulation in 2003, and then it was to be revised in 2005. The Regulation states that during Ramadan, (1) it is prohibited to open restaurant, food stall and entertainment houses; (2) it is also prohibited to eat, drink and smoke in restaurant, food stall and other public areas during the fasting hour. Everyone who sells food and drink in the public market are only allowed to open from 15.00 in the afternoon. Anybody who breaks the regulation point 1, can be punished by maximum 3 months in jail or Rp 50 million fine at the maximum. Anybody who breaks point 2 can be punished by maximum 3 months in jail or Rp 7.5 million fine at the maximum.

Mukhtar Sarman, a regular columnist for the local newspaper, Banjarmasin Post, published a column on 25 September 2006 entitled 'Bingung' (Confused), criticizing the regulation. He was confused, he said, because of three reasons. First, he cannot understand why the government regulate religious obligation for citizens. For him, the duty of the state is to regulate public affairs, while fasting as a Muslim

\footnotetext{
${ }^{43}$ Mujiburrahman, "Intra and Inter-Religious Dialogue in Contemporary Indonesia: a participant's point of view," Bulletin of Nanzan Center for Asia-Pacific Studies No.7 (June 2012), pp. 10-11.

${ }^{44}$ Robin Bush, "Regional Sharia Regulations in Indonesia: Anomaly or Symptom?," in Greg Fealy and Sally White (eds), Expressing Islam: Religious Life and Politics in Indonesia (Singapore: ISEAS 2008), pp. 174-191; Mujiburrahman, "The Politics of Shari'a: The Struggle of the KPPSI in South Sulawesi," in Martin van Bruinessen (ed.), Contemporary Developments of Indonesian Islam, Explaining the Conservative Turn (Singapore: ISEAS, 2013), pp. 145-189.

45 The following account is based on the documents published in Mukhtar Sarman, Mencari Kebenaran, Menuai Kecaman di Balik Kontroversi Perda Ramadan (Banjarmasin: LK3 and PK2PD, 2006).
} 
religious obligation is a private issue. The regulation, he said, seems to force all Muslims to fast during the Ramadan. Second, if God wills, He can force everybody to fast, but He does not. The reason is, God allows people to choose to obey or disobey Him. Why then the government forces everybody to fast? In fact, there is no guarantee that by implementing the regulation, people will become more pious. The third, the government uses its Satuan Polisi Pamong Praja abbreviated as 'Satpol PP' (a kind of 'civilian' police of the regional government, not the national police) to control or arrest people who break the regulation. "Is Satpol PP the army of God commissioned to control the piety of people?" he asked.

In response to Sarman's criticisms, on 2 October 2006, the Vice Major of Banjarmasin, Alwi Sahlan, published an article in Banjarmasin Post. First of all, he said that the regulation does not mean that the government forces all citizens to fast during Ramadan. It only prohibits people from eating and drinking publicly during the fasting hour. Anybody who wants to eat and drink, or does not want to fast privately, he or she is not covered by this regulation. Second, in Islam, religion and public affairs are not separated. It is true that Indonesia is not an Islamic state, but it is not secular either. There is a religious court in this country where Islamic family law is applied. Every government official should take an oath based on his/her religion. Thus, the regulation is in accordance with the state ideology, Pancasila. Third, to say that as if Satpol PP were the army of God is too much. For Sahlan, it is the duty of the Satpol PP, according to the law, to supervise the implementation of regional regulations.

The polemics, however, did not continue in the newspaper, but the discussion proceeded among the NGO activists, especially at the Institute for Islam and Social Studies (LK3). Mukhtar Sarman then published a tiny book with LK3 on the subject. In this book, in addition to the above article, Sarman argues that it is the duty of the ulama, not the government, to educate people to obey religious obligations. He also said that, the regulation is against the interest of the poor, the marginalized people who open food stall for daily living, including in Ramadan. They usually respect those who fast by covering their food stall with cloth. This is called in Banjarese 'warung sakadup'. To be sure, Sarman was not alone, but the dominant view seems to support the regulation. On the other hand, the regulation seems to be 
loosely implemented, and I have not heard about any who was put in jail because of breaking the regulation.

The last important issue is inter-religious relations. As has been discussed, during the New Order period, there were cases in which Muslim and Christian leaders were in tensions, even though there was no violence broke up. The rioters of 1997 also burned the churches and viharas. Since the New Order period, there have been attempts at building inter-religious harmony by the Ministry of Religious Affairs, especially through dialogue programs. In Banjarmasin, there is the Academy of Theology of the GKE Church. In early 1990s, when I was still a student at the Ushuluddin Faculty of the IAIN Antasari, there was cooperation between the Academy and the IAIN, especially for having an access to the library of the Academy. The Academy also invited a lecturer from the IAIN to teach Islam. Inter-religious dialogue became more commonly held during the early years of the Reformation Era, primarily as a reaction to the Muslim-Christian bloody conflicts in Ambon and Poso.

In the year 2006, the Minister of Home Affairs and the Minister of Religious Affairs issued a joint decree instructing the regional government to establish the so-called Inter-religious Harmony Forum (FKUB) at the provincial and district levels. In South Kalimantan, the FKUB was finally established in 2010. The members of the FKUB are representatives of the six religions (Islam, Protestantism, Catholicism, Buddhism, Hinduism, Buddhism, and Confucianism). The FKUB is funded through the regional government budget. The government of South Kalimantan Province has been generous with the funding. Therefore, the FKUB could manage many activities such as interreligious dialogue on certain actual issues, workshops on conflict resolution, meetings of religious leaders, organizing a pilot project of inter-religious harmony in certain villages, and publications. One noticeable positive impact of these activities is that religious leaders have been in contacts and communication.

In addition to the FKUB, the Ministry of Religious Affairs has continued its program on inter-religious dialogue. The participants of the program are usually religious leaders. However, more recently, the target of the program is mostly the young people, especially students of the Junior and Senior High Schools. The reason is, as has been mentioned, the young generation is more vulnerable to radical ideas and intolerant discourses. In 2015, the budget to build the office of the 
FKUB in some districts of the province was cancelled and transferred into a program called 'socialization of inter-religious harmony' to students at schools. I was invited to talk for the program in some schools. I found that students of minority religions at the beginning were hesitant to speak, but later on they became more open. I found that the dialogue season was always lively. A few students who were infected by radical views sometimes also asked critical questions. Given the positive responses from the schools, the program seems to be continued by the following years.

In addition to the government support, there are also activities of inter-religious meetings organized by private organizations. The most active is the LK3 mentioned above. The LK3 activists are mostly graduates from the IAIN (now UIN) Antasari or Lambung Mangkurat University. In carrying out its programs, the LK3 cooperates with Islamic, Protestant, Catholic, Buddhist or foreign institutions. They organized seminars, discussions, and publications. The most interesting and a bit controversial among Muslims is that the LK3 organizes a discussion in every Ramadan in cooperation with the Catholic Church, followed by fast breaking for Muslim participants. Besides the LK3, the most recent group concerned with inter-religious peace is the Gusdurian Network of South Kalimantan branch. The activists of the network come from different religious and ethnic backgrounds. As can be seen from its name, the Gusdurian network is intended to support Abdurrahman Wahid's idea of equal rights for all citizens and fighting against any discrimination.

Last but not least, in the last few years, the Bishop of the Catholic Church in Banjarmasin organized the so-called 'Open House' in which he invited Muslim leaders to come to visit him on the day of the New Year. The initiative of the Bishop is apparently a very good step to eradicate suspicions among Muslim politicians and leaders. It is noteworthy that during the gubernatorial elections of 2010, there was a rumor that the biggest Catholic Church in Asia was built in Batulicin. The Church is named Santo Vinsensius a Paulo, and it was blessed by the Vatican Ambassador on 1 October 2009. The rumor said that the permission to build the Church was given by the regent of the Tanah Bumbu district, and in return the regent received financial support from the Catholics for his gubernatorial elections campaign. The Catholic Church, however, decided to keep silence, to avoid further problems. Another case happened in 2011 in Kotabaru district. The 
Catholic Church in Kotabaru already got the permission from the regent to renovate its church building and to move its kindergarten into inside area of the church. However, the permission was finally withdrawn by the regent because of demonstration against the plan. Again, in order to avoid further problems, the Catholics decided to keep silence. These two cases, therefore, indicate that the minorities are still vulnerable to political games and majority pressure. ${ }^{46}$

\section{Conclusion}

We have discussed the historical overview of the dynamics of inter-religious relations in South Kalimantan. As usual, there are continuities and changes along the line of history. Early conversion to Islam in the $16^{\text {th }}$ century, and more intensive Islamization by the $18^{\text {th }}$ century, can be seen as the formative period of Islam in this region. The encounter and clash between the new religion and the existing beliefs and practices were unavoidable. The dialectic between the two seems to lead to a kind of synthesis in which local religious culture was Islamized or at least transformed into a more Islamic one. By the late $19^{\text {th }}$ century, the clash seems to move to another target, namely the colonial power associated with Christianity. By this period, Islam was transformed from the court into people movement against the colonial power. Islam started to be organized in society, especially through the Sufi Order.

By the first half of the $20^{\text {th }}$ century, the problem of the $18^{\text {th }}$ century apparently reappeared but with a different orientation. The reform of the $18^{\text {th }}$ century was intended to 'defeat' the existing religious 'rival', while the reform of the $20^{\text {th }}$ century was intended to make Islam more in line with modern rational ethos. The making of the Indonesian nation state by the second half of the $20^{\text {th }}$ century pushed the Banjarese Muslims to be involved in the ideological debates, and even in a rebellion against the state. It was on this occasion that the politics of ethnic and religious identities led to the partition of the province. During the New Order period, the fear of Christianization and the socio-political frustration sometimes led to tensions between Muslims and Christians, and a riot even put the churches and viharas as the target of attack. In the Reformation Era, the challenges are mostly about the increasing plurality within and without Islam. There is no

${ }^{46}$ Interview with Nugroho Susilo, 29 February 2016. 
realistic choice but to face the plurality with dialogue. Fortunately, the recent trends seem to be positive, thanks to the political democracy of this era, even though the threat of radicalism and intolerance is also there. Probably, the most crucial issue in the future is whether the government can narrow the wide gap between the poor and the rich, and whether the environmental crisis because of deforestation, coal mining and palm oil companies can be managed. The Banjarese War of the $19^{\text {th }}$ century and the riot of 1997 are good lessons telling us that social injustice will eventually lead to social unrest.]

\section{References}

\section{Books and Articles}

Abdullah, Mal'an. Syaikh Abdus-Samad al-Palimbani, Biografi dan Warisan Keilmuan. Yogyakarta: Pustaka Pesantren, 2015.

al-Banjari, Muhammad Arsyad. Tuhfat al-Räghibin. Banjarmasin: Toko Buku Murni, 1983.

al-Ghazali, Muhammad Ibn Muhammad. Faişal al-Tafriqah bain al-Isläm wa al-Zandaqah. M. Bejou (ed.). Damascus: Matba'at al-Sabah, 1993.

Ananta, Aris, Evi Nurvidya Arifin, M. Sairi Hasbullah, Nur Budi Handayani, and Agus Pramono. Demography of Indonesia's Ethnicity. Singapore: ISEAS, 2015.

Atha'illah, A. "Perkembangan Tarekat Sammaniyyah di Kalimantan Selatan." Khazanah Vol. 3 No.2, 2004, pp. 223-244.

Basry, Hassan. Kisah Gerilya Kalimantan (Dalam Revolusi Indonesia) $1945-$ 1949. Bandjarmasin: Jajasan Lektur Lambung Mangkurat, 1961.

Kisah Gerilya Kalimantan Periode Tabun 1945-1949. Jilid I dan II. Banjarmasin: Yayasan Bhakti Banua, 2003.

BPS Kalimantan Selatan. Kalimantan Selatan dalam Angka 2015. Banjarmasin: BPS Kalimantan Selatan, 2015.

Bradely, Francis R. "The Social Dynamics of Islamic Revivalism in Southeast Asia, the Rise of Patani School 1785-1909." Ph.D Thesis, University of Wisconsin-Madison, 2010.

Bush, Robin. "Regional Shariah Regulations in Indonesia: Anomaly or Symptom?." Greg Fealy and Sally White (eds). Expressing Islam: Religious Life and Politics in Indonesia. Singapore: ISEAS 2008, pp. 174-191. 
Daud, Alfani. Islam dan Masyarakat Banjar. Jakarta: PT Rajagrafindo, 1997.

---------. "Islamisasi Upacara Mandi-Mandi di Kalangan Masyarakat Banjar." Religika Vol.1 No.1 2000, pp. 69-92.

Daudi, Abu. Transliterasi Kitab Tuhfaturraghibin. Martapura: Yapida. 2000.

Feener, R. Michael. "A Re-Examination of the Place of al-Hallaj in the Development of Southeast Asian Islam." Bijdragen tot de Taal-, Land end Volkenkunde Vol.154 No.4, 1998, pp. 571-592.

Feith, Herbert. Pemilihan Umum 1955 di Indonesia. Trans. Nugroho Katjasungkana, Masri Maris and Prakitri Simbolon. Jakarta: Kepustakaan Populer Gramedia, 1999.

Hapip, Abdul Djebar. Kamus Banjar Indonesia. Bajarbaru: Grafika Wangi Kalimantan, 2006.

Hasan, Noorhaidi. "The Tuhfat al-Raghibin: the work of Abdul Samad al-Palimbani or Muhammadi Arsyad al-Banjari?." Bijdragen tot de Taal-, Land en Vulkenkunde. Vol. 163 No.1, 2007, pp. 67-85.

Ideham, M. Suriansyah et. al. Urang Banjar dan Kebudayaannya. Yogyakarta: Ombak, 2015.

Iqbal, Muhammad. "Menyulut Api di Padang Ilalang: Pidato Politik Soekarno di Amuntai, 27 Januari 1953." Undergraduate Thesis. Yogyakarta: Department of History, State University of Yogyakarta, 2009.

---------. "Kesatuan Rakjat yang Tertindas (KRjT): Pemberontakan Ibnu Hadjar di Kalimantan Selatan 1950-1963." Master Thesis. Jakarta: Department of History, University of Indonesia, 2014.

Jones, Russel. "Ten Conversion Myths from Indonesia." in Nehemia Levtzion (ed.). Conversion to Islam. New York: Holmes \& Maier, 1979, pp. 129-158.

Khotimah, Husnul. "Collective Memory Jumat Kelabu di Kota Seribu Sungai (Studi Kasus Kerusuhan Sosial 23 Mei 1997 di Provinsi Kalimantan Selatan dalam Perspektif Bina Damai)." Master Thesis. Yogyakarta: Postgraduate Program, State Islamic University, Sunan Kalijaga, 2016.

Kristiyanto, A. Eddy. Sejarah Keuskupan Banjarmasin. Banjarbaru: Grafika Wangi, 2013. 
Mandan, Arief Mudatsir. Napak Tilas Pengabdian Idham Chalid. Jakarta: Pustaka Indonesia Satu, 2008.

Mas'oed, Mochtar, Mochammad Maksum, and Muhammad Soehadha (eds). Kekerasan Kolektif, Kondisi dan Pemicu. Yogyakarta: P3PK Universitas Gadjah Mada, 2000.

Matheson, Virginia. "Conflict Without Resolution: the Banjarmasin War 1859-1905." Paper presented at the fourth Conference of Asian Studies Association of Australia, at Monash University, May 10-14, 1982.

Miles, Douglas. Cutlass and the Crescent Moon: A Case Study of Social and Political Change in Outer Indonesia. Sydney: Center for Asian Studies, Sydney University, 1976.

Mujiburrahman. Feeling Threatened: Muslim-Christian Relations in Indonesia's New Order. Amsterdam: Amsterdam University Press, 2006.

Mengindonesiakan Islam, Representasi dan Ideologi. Yogyakarta: Pustaka Pelajar, 2008.

"Intra and Inter-Religious Dialogue in Contemporary Indonesia: a participant's point of view." Bulletin of Nanzan Center for Asia-Pacific Studies No.7 June, 2012, pp. 1-20.

. "The Politics of Shari'a: The Struggle of the KPPSI in South Sulawesi." Martin van Bruinessen (ed.). Contemporary Developments of Indonesian Islam, Explaining the Conservative Turn. Singapore: ISEAS, 2013, pp.145-189.

-. "Islamic Theological Texts and Contexts in Banjarese Society: An Overview of the Existing Studies." Southeast Asian Studies Vol. 3 No.3, December 2014, pp. 611-641.

Noer, Deliar. Gerakan Modern Islam di Indonesia 1900-1942. Jakarta: LP3ES, 1980.

Noor, Yusliani. Islamisasi Banjarmasin Abad ke-15 sampai ke-19. Yogyakarta: Ombak, 2016.

PII. Kristenisasi di Kalimantan Selatan (Peristiwa 'Salob' dengan Rangkaianja). Bandjarmasin: PW PII Kalsel, 1969.

Ras, J.J. Hikajat Bandjar: A Study in Malay Historiography. The Hague: Martinus Nijhoff, 1968. 
Saifuddin, Achmad Fedyani. Konflik dan Integrasi, Perbedaan Faham dalam Agama Islam. Jakarta: Rajawali Press, 1986.

Saleh, M. Idwar. "Agrarian Radicalism and Movements of Native Resurrection in South Kalimantan (1858-1865)." Archipel, Vol. 9, 1975, pp. 135-153.

Salim, Hairus. Amuk Banjarmasin. Jakarta: YLBHI, 1997.

Sarman, Mukhtar. Mencari Kebenaran, Menuai Kecaman di Balik Kontroversi Perda Ramadan. Banjarmasin: LK3 dan PK2PD, 2006.

Sjamsuddin, Helius. Pegustian dan Temenggung: Akar Sosial, Politik, Etnis dan Dinasti Perlawanan di Kalimantan Selatan dan Kalimantan Tengah 1859-1906. Yogyakarta: Ombak, 2014.

Steenbrink, Karel A. Beberapa Aspek Tentang Islam di Indonesia Abad ke19. Jakarta: Bulan Bintang, 1984.

Suryadinata, Leo, Avi Nurvidya Arifin, and Aris Ananta. Indonesia's Population: Ethnicity and Religion in a Changing Political Landscape. Singapore: ISEAS, 2003.

Syaharuddin. "Organisasi Islam di Borneo Selatan, 1912-1942: awal kesadaran berbangsa urang Banjar." Master Thesis. Yogyakarta: Faculty of Humanities Gadjah Mada University, 2008.

Syukur, Asywadie. Pemikiran-Pemikiran Syekh Muhammad Arsyad alBanjari dalam Bidang Taubid dan Tasawuf. Banjarmasin: Comdes, 2009.

---------. "Naskah Risalah Tuhfatur Raghibin.” Interim Report. Banjarmasin: IAIN Antasari, 1990.

Toru, Nomura. "Magotaro: An Eighteenth Century Japanese Sailor's Record of Insular Southeast Asia.” Sari 27, 2009, pp. 45-66.

van Bruinessen, Martin. Kitab Kuning, Pesantren dan Tarekat. Yogyakarta: Gading, 2012.

van Dijk, C. Rebellions under the Banner of Islam: The Darul Islam in Indonesia. Leiden: KITLV, 1981.

\section{Interviews}

Darius Dubut, 27 September 2015

Susilo Nugroho, 29 February 2016 